\title{
The Factors Related To the Severity of Traffic Accident Victims of Bikers at Emergency Department (Igd) of General Hospital
}

\author{
Nani Yuniar ${ }^{* 1}$, Denvi Vitayala Zainuddin ${ }^{2}$, Andi Faizal Fachlevy ${ }^{2}$, Hariati Lestari $^{3}$, Hartati Bahar ${ }^{4}$, \\ Lymbran Tina ${ }^{3}$
}

\begin{abstract}
Traffic accidents are road traffic incident in which at least caused by a vehicle which caused injury, damage or loss to the owner or the victim. The purpose of this study was to determine the identifying factors relationship with the severity of traffic accident victims of bikers at emergency department (IGD) of General Hospital in Kendari. Research method is analitytical research with cross sectional approach. Research sites in the city district general hospitals kendari and sample was 443 people. The results showed thad there is no relationship between the use of helmets, use of cell phones with the severity of victims of traffic accidents motorcycle. There is a relationship between the speed of the severity of traffic accident victims motorcycle on emergency Department (IGD) patients in general hospital kendari city.
\end{abstract}

Keywords - Traffic Accidents, Helmet Use, Cell Phone Use, and Speed.

\section{INTRODUCTION}

One of the main causes of death are injuries. WHO projections, in 2005 the injury be ranked fourth leading cause of death in all ages around the world, and ranked third on the global burden. But population growth and prosperity be one cause of the increase in road traffic accidents. sometimes traffic accidents on these roads can lead to injuries or material losses even to eliminate human lives [1].

In 2013 the number of occurrences of traffic accidents in Indonesia is 101037 , with the number of victims of accidents as much as 159677 people. the victim died as many as 25157 people with CFR $15.75 \%$, seriously injured 29544 people with the proportion $18: 50 \%$, and minor injuries 104.978 people with the proportion of $65.74 \%$. In Southeast Sulawesi in 2015 there were 821 occurrences of traffic accidents, the number of victims of accidents 1,295 people, victim died as many as 166 people with 20 CFR, 21\%, 277 seriously injured people to the proportion of $24.53 \%$ and slightly injured 852 people with the proportion of $75.46 \%$. In the city of Kendari in 2014 there were 316 occurrences of traffic accidents. The

\footnotetext{
$*^{1}$ Nani Yuniar (corresponding Author): Faculty of Public Health, Universitas Halu Oleo, Sotheast Sulawesi, Indonesia

${ }^{2}$ Denvi Vitayala Zainuddin, Andi Faizal Fachlevy: Department of Environment health, Faculty of Public Health, Universitas Halu Oleo, Sotheast Sulawesi, Indonesia

${ }^{3}$ Hariati Lestari, Lymbran Tina: Department of Epidemiology, Faculty of Public Health, Universitas Halu Oleo, Sotheast Sulawesi, Indonesia

${ }^{4}$ Hartati Bahar: Departmen of promotion and health Behavior, Faculty of Public Health, Universitas Halu Oleo, Sotheast Sulawesi, Indonesia
}

number of victims of accidents as many as 425 people. The victim died 54 at 17:08 CFR\%, 122 seriously injured people to the proportion of $32.88 \%$ and slightly injured 249 people with the proportion of $67.11 \%$. Then in 2015 decreased, there were 296 occurrences of traffic accidents. The number of victims of accidents 362 people. The victim died as many as $33 \%$ of people with CFR 11:14, 97 seriously injured people to the proportion of $29.48 \%$ and slightly injured 232 people with the proportion of $70.51 \%$ [2].

In 2013 the number of traffic accident victims be 679 people. The victim died with CFR 1:42 10\%, 77 seriously injured people to the proportion of $11: 50 \%$ and 592 lightly injured people to the proportion of $88.49 \%$. In 2014 the number of traffic accident victims be 757 people. The victim died 13 people with CFR $1.71 \%$, serious injuries increased by 61 people with the proportion of $8.19 \%$ and slightly injured 683 people with the proportion of $91.80 \%$. Then there was an increase in 2015 with 895 occurrences of traffic accidents. The victim died as many as $10 \%$ of people with CFR 1:11, 85 seriously injured people to the proportion of $9.60 \%$ and slightly injured 800 people with the proportion of $89.38 \%$ [3].

\section{MethodS}

Using type analytical research with cross sectional study. implemented in 2016 and is housed in the General Hospital of Kendari. A sample of 443 people. Selection of the sample using simple random sampling method. Variable consisted of Severity of Traffic Accidents, Use of Helm, Use of Cell Phones and Free. Data were analyzed using univariate analysis and bivariate analysis.

\section{RESULT AND DISCUSSION}

The results of the bivariate analysis of factors causes of traffic accidents and the severity of traffic casualties motorcyclists can be seen in table I. 
TABLE I

Results Of Univariate ANALYSIS AND A FaCtor CONTRIBUting To THE SEVERITY OF TRAFFIC ACCIDENTS MOTORCYCLE USERS

\begin{tabular}{|l|c|c|}
\hline \multicolumn{1}{|c|}{ Variable } & Frequency (n) & Percentage (\%) \\
\hline The severity of the accident & & \\
victim & 211 & 47.8 \\
Minor injuries & 232 & 53.5 \\
Serious wount & & \\
\hline The use of helmets & 119 & 26.7 \\
Standardized & 324 & 73.3 \\
Non standardized & & \\
\hline Use of Cell Phones & 266 & 60.0 \\
Use & 177 & 40.0 \\
Don't Use & & \\
\hline Vehicle speed & 152 & 34.4 \\
Moderate & 290 & 65.6 \\
Fast & \multicolumn{2}{|l}{} \\
\hline
\end{tabular}

The results of the analysis of Table I shows that the motorcycle rider as much as $53.5 \%$ suffered serious injuries. Users helmet standards are not as much as $73.3 \%$, which is using a mobile phone while driving as much as $60 \%$ and the driving speed is very fast as much as $65.5 \%$.

A. Relationships using helm with severity of victims of traffic accidents motorcycle riders in igd general hospital

TABEL II

ANALYSIS OF THE RELATIONSHIP WITH THE SEVERITY OF THE PATIENT'S USE OF HELMETS TRAFFIC ACCIDENT MOTOR CYCLE USERS

\begin{tabular}{|c|c|c|c|c|c|c|c|c|}
\hline \multirow{3}{*}{$\begin{array}{l}\text { The use of } \\
\text { helmets }\end{array}$} & \multicolumn{4}{|c|}{$\begin{array}{l}\text { The severity of the } \\
\text { accident victim }\end{array}$} & \multirow{2}{*}{\multicolumn{2}{|c|}{ Amount }} & \multirow{3}{*}{$\begin{array}{c}\mathbf{P} \\
\text { Value }\end{array}$} & \multirow{2}{*}{ phi Ø } \\
\hline & \multicolumn{2}{|c|}{$\begin{array}{c}\text { Minor } \\
\text { Injuries }\end{array}$} & \multicolumn{2}{|c|}{$\begin{array}{l}\text { Serious } \\
\text { Wound } \\
\end{array}$} & & & & \\
\hline & $\mathrm{n}$ & $\%$ & $\mathrm{n}$ & $\%$ & $\mathrm{n}$ & $\%$ & & \multirow{4}{*}{0,228} \\
\hline Standardized & 99 & 66,7 & 49 & 33,3 & 148 & 100 & \multirow{3}{*}{0,054} & \\
\hline Non standardized & 121 & 40,9 & 175 & 59,1 & 296 & 100 & & \\
\hline Total & 212 & 47,8 & 231 & 52,2 & 443 & 100 & & \\
\hline
\end{tabular}

The results showed that there was no association between the use of helmets with the severity of the accident victim in patients IGD Regional General Hospital. other studies show that helmet use was not statistically sufficient evidence of an effect on the severity, but the effect on the level of awareness of the driver involved in the accident [4].

Severity is influenced by the level of consciousness, thus indirectly affect the use of helmets severity. compliance with the level of traffic trauma in a traffic accident motorcycle driver have been studied [5].

Accidents involving motorcycle riders or passengers can lead to serious injuries, even death. This is due to the lack of protection of bikers. When compared to cars, motorcycles do not have the instruments absorbers, seat belt in order to withstand the impact.

The wound in the head is the biggest part of the severe and fatal accidents suffered by motorcyclists. Type of head damage such as cracking on the cranium. The location of the wound on the forehead, back or side of the head, especially in the right position to deal with traffic from the front.

Excellence Motorcycles have a smaller size makes it easy to oncoming motorists move in traffic. however, this can make the motorcycle riders involved in accidents that can easily cause serious injury to the rider.
Further impact of head injury is that it can cause disturbances in the brain, central nervous system and spinal cord top. Motorcyclists also could have a concussion, injury to the foot even died. To protect motorists from traffic accidents often occur, the government also requires the use of helmets SNI (Indonesian National Standard) to anticipate the possibility that worse.

The results showed that most respondents do not use a helmet because of the close distance factor. With regard that the more meninnginya underestimated the severity of the traffic accident victims motorcycles.

In the execution of the application program helmet standards in Kendari, Kendari City Traffic Polrestabes has prioritized the application of proper coordination with the total police force of Kendari which Polrestabes and the entire police station in the city of Kendari. Police as a police force that can optimize the lowest part of the implementation of helmet standards program throughout the city of Kendari. Coordination between Satlantas Polrestabes the entire police station in the city of Kendari done to achieve standardization policy implementation program in accordance with Regulation Legislation Number 22 Year 2009 regarding Traffic and Road Transportation, which requires all road users, especially users of two-wheelers to wear helmets in accordance with SNI standard.

Program implementation of helmet standards have enormous benefits. The benefits are felt by the public, among others, can improve the security and safety when driving on the highway and can reduce the high risk of a fatal accident for the rider. Motorcyclists urged to always use a helmet in accordance with applicable regulations.

Achievement of the objectives of the program implementation is not yet maximal standardized helmet, because in actual experience various obstacles, such as suburban communities still do not understand the purpose of the implementation of the policy. Many violations and traffic accidents in rural areas in Kendari.

Implementation process consists of the improvement of facilities and infrastructure provided by Polrestabes Kendari to support the process of socialization. Facilities and infrastructure are provided such as the installation of banners, distribution of brochures on how to use a helmet (directly to the motorcycle rider), as well as the delivery of information through the mass media. Implementation of the program's implementation helmet standards necessary to supplement the activities that are more effective in the socialization process. So that people can understand the purpose of the policy, and shape its program of activities must be done continuously.

Associated with the implementation of policies, actors implementing the policy has primary responsibility to implement policies to the target group which is a whole community of Kendari. An active policy implementers must provide and serve. Expected that people can understand clearly and have the benefit after following the policy.

Facilities and infrastructures is a supporting tool in the implementation of the policy. About the completeness and the quality and quantity must be considered in accordance with the needs of the policy program. If it is able to provided well, at least make it easier for executive actors in achieving its policy objectives. 
Implementation of helmet standards in Kendari by the Traffic Polrestabes Kendari city has been in communication with providing information to the public through the mass media and radio, distribution of brochures or pamphlets free of charge to motorists, the socialization directly to a number of areas, and provide information on the rules and cross. Particularly regulations that require wearing a helmet SNI standards.

Indicators clarity of communication is also important to determine the success of the implementation of public policy. The effective implementation happens if the decision makers already know what they will do. Knowledge of what they would do to run smoothly when communication goes well. Besides policy communicated must be precise, clear and consistent. Clarity This communication includes transmitting information between Polrestabes with Traffic, as well as between Satlantas with the community.

In practice there are still many people do not understand the intent of the government to implement the obligation to use helmets that comply with safety standards this. Thus, the number of traffic violations will rise higher and higher. Compliance with the driver of the provisions for the use of a standard helmet, generally no more than an attempt to escape from the police. While the philosophical value of these provisions is not a driver of self-awareness to the ISOstandard helmet use.

Program implementation of this standard helmet on implementation has not run smoothly because many people do not understand about the purpose of the program. Society as a target group in the implementation of helmet standards program, believes that this program only benefited a group of parties, namely employers helmet and of course the police will do a lot of speeding tickets.

Basically people as the target groups to support this policy regulations. In the implementation is not running optimally, so there are still many people do not understand the purpose of this application program. In addition, the relatively high penalties for the perpetrators of the offense of not using helmets that comply with safety standards, making many people, especially the motorcycle feel too heavy financial penalties are applied. Expected in the next execution, the police have to work harder, so that people can understand the purpose of the program is the implementation of ISO-standard helmet. Of public awareness needs to be fostered and developed through development patterns more effectively and intensively.

\section{A. Relationships Using Cell Phone With Severity of Traffic Accident Victims at the District General Hospital}

The use of mobile phones is the cell phone use while driving. test results show no association between mobile phone use with the severity of traffic accident victims motorcycle in patients IGD Regional General Hospital of Kendari.
TABLE III

ANALYSIS OF THE RELATIONSHIP OF CELL PHONE USE WITH THE SEVERITY OF THE PATIENT'S TRAFFIC ACCIDENT MOTOR CYCLE USERS

\begin{tabular}{|c|c|c|c|c|c|c|c|c|}
\hline \multirow{3}{*}{$\begin{array}{l}\text { Use of Cell } \\
\text { Phones }\end{array}$} & \multicolumn{4}{|c|}{$\begin{array}{l}\text { The severity of the } \\
\text { accident victim }\end{array}$} & \multirow{2}{*}{\multicolumn{2}{|c|}{ Amount }} & \multirow{2}{*}{$\begin{array}{c}P \\
\text { Value }\end{array}$} & \multirow{2}{*}{ phi Ø } \\
\hline & \multicolumn{2}{|c|}{$\begin{array}{c}\text { Minor } \\
\text { Injuries }\end{array}$} & \multicolumn{2}{|c|}{$\begin{array}{l}\text { Serious } \\
\text { Wound } \\
\end{array}$} & & & & \\
\hline & $\mathrm{n}$ & $\%$ & $\mathrm{n}$ & $\%$ & $\mathrm{n}$ & $\%$ & \multirow{4}{*}{1,000} & \multirow{4}{*}{0,009} \\
\hline Use & 112 & 48,1 & 110 & 51,9 & 222 & 100 & & \\
\hline Do not Use & 100 & 47,2 & 121 & 52,8 & 221 & 100 & & \\
\hline Total & 212 & 47,8 & 231 & 52,2 & 443 & 100 & & \\
\hline
\end{tabular}

The results of analysis of this study showed that there was no correlation with the severity of the cellular phone usage victims of traffic accidents motorcycle users. The results of this study differ from previous research that states that an association of cell phone use as a factor in traffic accidents motorcycle and biological use of mobile phones as a risk factor for the incidence of motorcycle traffic accidents [6]. Other studies have also suggested that there is a relationship of cell phone use with the incidents resulted in casualties on the severity of the rider [7].

Motorists using mobile phones while driving, face a risk of collision 4 times when compared to riders who do not use cell phones. collisions are most common in riders due to cell phone use. Therefore, for motorists who use mobile phones risk of traffic accidents by 4.3 times compared to riders who do not use cell phones. , While research conducted by the finding that the use of mobile phones while driving causes fortunate consequences in the event of a collision on the highway. Driving while using a cell phone (talking, texting, use the facilities of the game) is an activity that endanger the safety of the riders themselves and other road users. Communicating using a mobile phone while driving will distract the driver in running his vehicle so that conditions like this opportunity for the RTA on the highway [8].

The majority of motorists who do not use cell phones while driving, stating not to use cell phones while driving because they fear the lack of focus, causing an accident while driving. they also said that during driving should not use mobile phones because it can endanger themselves and others.

Most motorists are aware of the dangers of cell phone use while driving. due in large cities congested road they do not pay attention to the dangers of cell phone use while in the small town streets were deserted of vehicles as well as better awareness for not using a cell phone while driving.

\section{B. Speed Relationships With Severity of Victims of Traffic Accidents in the Regional General Hospital}

Driving speed is how much the speed of vehicles driven by motorcyclists in driving. the results showed no relationship between the speed of the severity of traffic accident victims motorcycle in patients IGD Regional General Hospital of Kendari. 
TABLE IV

THE ANALYSIS OF VEHICLE SPEED USAGE RELATIONSHIP WITH THE SEVERITY OF THE PATIENT'S TRAFFIC ACCIDENT MOTORCYCLE USERS

\begin{tabular}{|c|c|c|c|c|c|c|c|c|}
\hline \multirow{3}{*}{ Speed } & \multicolumn{4}{|c|}{$\begin{array}{l}\text { The severity of the } \\
\text { accident victim }\end{array}$} & \multirow{2}{*}{\multicolumn{2}{|c|}{ Amount }} & \multirow{2}{*}{$\begin{array}{c}P \\
\text { Value }\end{array}$} & \multirow{2}{*}{ phi $\varnothing$} \\
\hline & \multicolumn{2}{|c|}{$\begin{array}{l}\text { minor } \\
\text { injuries }\end{array}$} & \multicolumn{2}{|c|}{$\begin{array}{l}\text { serious } \\
\text { wound } \\
\end{array}$} & & & & \\
\hline & $\mathrm{n}$ & $\%$ & $\mathrm{n}$ & $\%$ & $\mathrm{n}$ & $\%$ & \multirow{3}{*}{0,003} & \multirow{3}{*}{0,337} \\
\hline $\begin{array}{l}\text { Moderate } \\
\text { Fast }\end{array}$ & $\begin{array}{c}129 \\
93 \\
\end{array}$ & $\begin{array}{l}71,0 \\
35,6 \\
\end{array}$ & $\begin{array}{c}53 \\
168 \\
\end{array}$ & $\begin{array}{l}29,0 \\
64,4 \\
\end{array}$ & $\begin{array}{l}182 \\
261 \\
\end{array}$ & $\begin{array}{l}100 \\
100 \\
\end{array}$ & & \\
\hline Total & 212 & 47,8 & 231 & 52,2 & 443 & 100 & & \\
\hline
\end{tabular}

Results of analysis showed an association of mobile phone usage with the severity of traffic accidents motorcycle users. This is consistent with previous studies which stated that the speed has a significant relationship with keparahn victims of traffic accidents [9]. IGD research results in Fatmawati, states that high speed has a relationship with the severity of traffic accident victims motorcycle [10].

Incidence of traffic accidents in urban mainly caused by a high rate of speed riders were more than $50 \mathrm{~km} / \mathrm{h}$. riders at high speed have the opportunity to accidents at 2:54 times $(\mathrm{OR}=2.54)$ compared with the low-speed riders, $(95 \% \mathrm{CI}=$ 1623.98) [11]. zone speed of $20 \mathrm{~km} / \mathrm{h}$ is an effective measure in reducing injuries and deaths from traffic accidents [12].

Acceleration of the vehicle that carried the riders affected by a number of factors, factors related to the driver (age, gender), factors related to roads and vehicles (the state of roads, the quality, the road surface, vehicle power, and maximum speed), whereas environmental factors and the road is the composition and density of the road, speed prevailing weather conditions.

Motorists in running vehicles should pay attention to speed signs also pay attention to other conditions such as rainy weather, vehicle density and other factors that do not allow the vehicle to be driven at high speed. Riders sometimes forget to pay attention to signs of speed and other circumstances. In fact, at high speed, the rider will be difficult to control the vehicle if it is willing to stop the vehicle suddenly so will lead to traffic accidents.

The risk for the occurrence of death and injury increases with increase in driving speed. Vehicle speed of 20 meters per hour has a $5 \%$ risk of causing death while the speed of 85 meters per hour increased the risk of death to $85 \%$. Motorcycle accident due to high speed when driving the vehicle in general suffered a severe injury due to clash intense and powerful that allows the victim was thrown away from the spot of the incident.

The physical condition of the road as well as a seamless no significant difference in the proportion of injury severity. Smooth road conditions encourage motorcyclists to accelerate the speed while the condition of the road motorcyclists are usually less cautious in driving the vehicle though at a low speed.

\section{CONCLUSION}

There was no association of Use Helm and Use of Cell Phones with the severity of traffic accident victims in hospital emergency room patients Kendari. While the speed relationship exists with the severity of traffic accident victims in hospital emergency room patients Kendari. enactment of the rules in the drive to wear helmets international standards, do not use cell phones while driving, and keep the vehicle speed motorcycle.

\section{ACKNOWLEDGMENT}

We would like to extent our thanks to all staffs and respondents at emergency department general hospital area, the city of Kendari, Southeast Sulawesi, Indonesia, for allowing to conduct some observational survey and interview.

\section{REFERENCES}

[1] H. Jeffry Rio, Factors Contributing And Traffic Accident On Motorcycle Riders In the city of Medan, North Sumatra, 2012. http://repository.usu.ac.id/handle/123456789/34939 accessed on December 5, 2015)

[2] Regional Police Southeast Sulawesi, Numeric Data Reports Traffic Accident Kendari, Kendari, 2015

[3] Public Hospital Regional Kendari City, Accident Numeric Data for 2012 to 2015, the city of Kendari, 2015.

[4] Sutarto, Effect of Helm and Vehicle Speed On The Level Weighing Trauma Due to Traffic Accidents Motorcycle driver, thesis, Diponegoro University Graduate Program. Semarang, 2012. (Http://eprints.undip.ac.id/13721/ accessed on December 6, 2016)

[5] Muhidin, Relationship Between Passes Cross-Compliance With Trauma Levels At Motorists Traffic Accidents Motorcycle At IGD Hospital Dr. Wahidin Sudirohusodo, RSU Daya And RSU Baji, Makassar, 2012.

[6] Sahabudi, As riders Risk Factors Occurrence of Traffic Accidents Motorcycle, Yogyakarta, 2011.

[7] N. Mulyono, Knowledge, Attitude and Behavior High School Students In Motorcycle Accident Prevention, Bekasi, 2014.

[8] P. S. McEvoy, M. R. Stevenson, M. Woodward, Phone Use And Crashes While Driving: A Representative Survey Of Driver In Two Australia State, MJA, 2006.

[9] Marsaid, Factors Associated With Traffic Accidents In Genesis Riders Motorcycle Police In Area Malang, East Java, 2003.

[10] W. Riyadina, "Profile Severity of Injuries In Motorcycle Accident Victims In Fatmawati Hospital Emergency Room", Universal Medicina, 2007, Vol. 26, (2), pp. 64-72.

[11] G. Qirjako, G. Burazer, B. Hysa, E. Roshi, "Factors Associated With Fatal Traffic Accidents In Irana Albania”, Journal Croat Med., 2008.

[12] C. Grundy, R. Steinbach, P. Edwards, J. Green, B. Amstrong, P. Wilkinson, Effect of 20 Mph Traffic Speed Zones On Road Injuries In London, 1986-2006. Controlled Interrupted Time Series Analysis, 2009. 